\title{
Importance of Good Business Writing Skills
}

\author{
Bindu Ranaut \\ General Education Instructor \\ West Coast University \\ Irvine, California, United States
}

\begin{abstract}
Effective communication is important for every company's success, today more than ever. As our workplace becomes more and more global in focus, the need to be understood efficiently and correctly has become imperative. Whether the communication is internal or external among customers, clients, or contractors, success in business depends upon mastering good communication skills.
\end{abstract}

Keywords: Communication, Business communication, effective Communication, Writing Skills.

\section{Importance of Good Business Writing Skills}

Communication skills, including writing, are one of the most important transferable skills that workers possess. Most business professionals, such as marketing, finance, and research and development managers, need excellent writing skills to properly convey ideas and concepts. There are many reasons that writing skills are important in the business world. During a regular business day, bosses write emails to employees notifying them of meetings or providing instructions for specific projects. These written messages must be concise and self-explanatory, so workers can be productive and not waste time asking for further instructions. Business people are busy and wellwritten communications help save time. Additionally, good writing adds to the credibility of the writer and reflects positively on a company's image. The unit for this project is taken from professional writing for business communication. Professional writing is a specialized field of communication whose purpose is to convey information accurately and effectively. One in a professional environment can have the greatest ideas in the world, but those ideas will be of no importance to one's company, one's readers, or one's career if those ideas are not expressed clearly and with a positive tone, that meets the readers' needs. In an age when we have so many media choices and so many written messages to create, having a strong and well-practiced process is important to one's success. In addition, knowing when to use the right formats for writing messages is important. It makes all the difference between how one's message is being read and understood.

\section{Rationale}

For effective communication, the writing should be practical, factual, concise, clear, and persuasive. In business, every document, no matter how large or small it is, is a reflection of the company. Therefore, professional writing calls for higher standards than other types of writing because business decisions are being made based upon what we put down in writing. Business communication requires a high level of skill and attention so to meet this requirement one needs to develop writing skills that will not only help them communicate effectively in everyday tasks, but will also help them advance in their careers. Communication in today's business environment is clearly a challenge, but one can face this challenge by learning some of the basic characteristics of professional writing, such as clarity, active voice, conciseness, fluency, positive tone, completeness, you-attitude, non-discriminatory language, confidence, and graphic highlighting.

\section{Needs Analysis of Business Writing}

Writing skills are important for all the business students, business school graduate and employer. Employers these days want to hire the graduates who excel in writing and communication, so that it helps, the organizations could achieve their goals. If one possesses good communication skills it is a plus in getting a good job and it opens many other doors for new opportunities. In addition, it is also believed that people who cannot write and communicate well might not be considered for promotion. Not only are excellent writing skills important for graduates who plan to work for medium-to-large organizations, but they are also important to those who plan to own their own businesses. 
Business experts and academics often consider writing skills as one of the most important qualifications that employees should possess. However, it has been noted that not only business employees, but recent college graduates also have serious writing deficiencies (Quible, 2007). Further, the researchers observed that student writing is not at par based on the feedback from policy makers and business leaders. Consequently, American businesses have spent billions of dollars annually to remediate these shortcomings (Quible, 2007). Some scholars believe that the development of advanced writing skills is not given importance and are often neglected in American schools. According to Kellogg \& Whiteford (2009), college graduates lack the many skills that are required in work place, and as a result of this weakness poorly written documents can cause employees to reread instructions, perform tasks incorrectly and miscommunication with their customers. College graduates will need to communicate both internally and externally, nationally and internationally. The ability to write clearly and to "critique, evaluate, and synthesize information" is critical for success in business. The National Commission on Writing (2004) noted that "technical reports, formal reports, and memos and correspondence" were written on a regular basis. People who cannot write and communicate clearly will not be hired and if hired are unlikely to last long enough to be considered for promotion.

\section{Communication and Technology}

Technology has also changed the business writing dynamic. According to Davies \& Birbili (2000), "Writing is becoming ever more central and crucial to the world of work, with computers on every desk, email and the internet adding to the world's written words in almost epidemic proportions" (p.2). With the evolution of technology and business today via e-mail, business writing skills have become even more important. Businesses these days rely on e-mail as a communication tool for business interactions, the way that they write will affect the decisions of prospective customers with regard to whether or not the customers choose to do business with them. Today's students are doing a lot of writing using technology before they even enter college or the workplace.

\section{Performance Analysis}

Assurance of learning continues to be a hot topic in higher education. Both accreditation agencies and employers are asking a key question: Are we graduating students who actually have the knowledge and skills that we promise and that the marketplace demands? (May, Thompson,\&Hebblethwaite,2012). The expectations of employers from the students to graduate with good communication and soft skills, in addition to finance, marketing, and strategy. The other skills businesses are looking at are, communication skills and the ability to work well within a team. These days the graduates lack effective communication and effective writing skills, this calls for a great concern for corporate executives (Middleton, 2011), and along with this the graduate faculty also complains about students do not meet expectations in professional writing.

Poor writing skills can result in significant difficulties for students and businesses. (Carnes, Awang\&Smith,2015). If the good communication skills are absent, it makes the students face limited career choices and lower earnings potential. To improve their skill sets and experience success, increasing numbers of students need additional writing remediation (Lenhart, Arafeh, Smith, \& Macgill, 2008). A survey conducted by The National Commission on Writing for America's Families, Schools, and Colleges (2004) revealed that effective writing is fundamental in today's professional environment. The Commission refers to writing as a "threshold skill" for salaried employment and advancement. Occupational and individual success in the United States is dependent on one's ability to portray thoughts logically and clearly on paper. 


\begin{tabular}{|c|c|}
\hline Marger's Performance Analysis Questions. & Possible Solutions \\
\hline Performance analysis of business graduates. & $\begin{array}{l}\text { Majority of firms assess writing skills when considering } \\
\text { hiring and promotion decisions, that writing skills of recent } \\
\text { graduates are generally considered unsatisfactory, and that } \\
\text { writing skills are essential for individuals desiring to achieve } \\
\text { higher level salaried positions (National Commission on } \\
\text { Writing,2004) }\end{array}$ \\
\hline $\begin{array}{l}\text { Possible problem } \\
\text { Is it required? }\end{array}$ & $\begin{array}{l}\text { Writing well and effectively in today's rapidly changing } \\
\text { business environment is a lot more complicated than simply } \\
\text { working on your spelling, grammar, and punctuation skills; } \\
\text { though these, of course, are important, too. }\end{array}$ \\
\hline Is it a skill deficiency? & $\begin{array}{l}\text { Yes, it is. Employers frequently complain about the state of } \\
\text { their employees' writing skills. }\end{array}$ \\
\hline Could they do it? & $\begin{array}{l}\text { Yes. Effective communication is important for every } \\
\text { company's success, today more than ever. As our workplace } \\
\text { becomes more and more global in focus, the need to be } \\
\text { understood efficiently and correctly has become an } \\
\text { imperative. }\end{array}$ \\
\hline Is the skill used often? & $\begin{array}{l}\text { Yes, all the time. Employers say that they look positively at } \\
\text { candidates whose résumés list business communication } \\
\text { courses (Hynes \& Sigmar, 2009). }\end{array}$ \\
\hline Could they do it if their lives depended on it & $\begin{array}{l}\text { Whether that communication is internal between employees } \\
\text { of a company, or external between employees and customers, } \\
\text { clients or contractors, success in business depends upon using } \\
\text { good communication skills. Today, most professionals agree } \\
\text { that the higher you move up the company ladder, the more } \\
\text { important competent communication skills become. }\end{array}$ \\
\hline Obstacles in performing the action. & $\begin{array}{l}\text { Writing effective business messages isn't always easy. Often, } \\
\text { professional writers encounter obstacles that decrease the } \\
\text { effectiveness of their print and electronic documents. Some } \\
\text { examples of obstacles are as follows: } \\
\text { - Technology failures } \\
\text { - Misunderstandings } \\
\text { - Cultural differences } \\
\text { - Exaggeration } \\
\text { - Information overload } \\
\text { - Lack of feedback }\end{array}$ \\
\hline Can the success be achieved? & $\begin{array}{l}\text { Effective business messages share some common traits. } \\
\text { According to Business Communication Today, effective } \\
\text { business messages: } \\
\text { - Provide practical information } \\
\text { - Give facts rather than impressions } \\
\text { - Clarify and condense information } \\
\text { - State precise responsibilities } \\
\text { - Persuade others and offer recommendations } \\
\text { Applying these characteristics in writinghelp prevent most } \\
\text { common communication problems. }\end{array}$ \\
\hline Is desired performance rewarding? & $\begin{array}{l}\text { Interpersonal communication skills can and must be learned } \\
\text { and are essential for influencing people and business } \\
\text { progress, and business communicators can practice a blend of } \\
\text { humor, humility, and honesty combined with nonverbal skills } \\
\text { such as eye contact, appropriate facial expression, and correct } \\
\text { body language to be optimally effective (Conrad, \& } \\
\text { Newberry, 2012). }\end{array}$ \\
\hline
\end{tabular}

Adapted from R. F. Mager, Making Instruction Work or Skill bloomers, p. 53, 1988.

\section{Learner Analysis}

Learning analysis is a procedure completed in addition with a needs assessment. The learner analysis process involves the designing of lessons using characteristics of the target audience (Brown \& Green, 2016). For effective communication, the writing should be practical, factual, concise, clear, and persuasive. 
In business, every document, no matter how large or small it is, is a reflection of the company. Therefore, professional writing calls for higher standards than other types of writing because business decisions are being made based upon what we put down in writing. Business communication requires a high level of skill and attention so to meet this requirement one needs to develop writing skills that will not only help them communicate effectively in everyday tasks but will also help them advance in their careers. Communication in today's business environment is clearly a challenge, but one can face this challenge by learning some of the basic characteristics of professional writing, such as clarity, active voice, conciseness, fluency, positive tone, completeness, you-attitude, non-discriminatory language, confidence, and graphic highlighting.

\section{The Learner Analysis Process}

The learner analysis process involves gathering data either through observation or published data about participants in a given class. Once the information is gathered, the instructional designer(s) must determine which methods are best for providing instruction to the participants with the hope all will comprehend the new instructions and acquire the new skill sets. Mager's approach to Learner Analyses is used throughout this paper.

\section{Task Analysis for Business Communication Class}

While designing an instruction the designers should take in account the level of learners understanding and what will they be able to accomplish. To identify these requirements, it is important to identify what kind of content to include in the instruction, and in what order it should be put in. A systematic process that is used to determine this information is called task analysis (Brown \&Green, 2016).

\section{Business Communication Requirements}

One of the leading factors that help individual succeed is to possess the effective communication skills both verbal and written. Communication skills play an important role as other roles one has to play in the business also depend on how well one can communicate his or her thoughts; this includes teamwork, leadership, planning, organizing, and more. However, many researchers are of the view that there is dearth of people who possesses these critical communication skills in contemporary business contexts (Waldeck, Helmuth \& Marcia,2012). As the businesses are going global, the communication process in business organizations is also changing, now most of the communication is done by using new technologies. Not only this there is also an increased demand of diverse and intercultural communication skills. Therefore, to meet these global requirements new communication competencies may be required.

\section{Skills and Goals}

With globalization, it has become essential professional skill to possess great communication and writing skills. Therefore, students, especially the management students, are required to take business communication classes to develop these skills, as these skills will be helpful in securing a job and advancing their career. Many students even in graduated classes struggle in improving the essential writing skills. The main reason to have such apprehension is that they think they are not good writers and struggle with writing even after taking many English classes throughout. Writing instruction typically does little to lessen writing apprehension, but fostering writing self-efficacy can both diminish writing apprehension and further writing development (Mascle,2013).

\section{Task Analysis}

Task analysis as stated by Smith and Ragan (1999) is the goals are transformed into a guide to be used for instructional design. That is the learners should be able to accomplish the goals by the end of the instruction and they should be aware of the prerequisite skills and knowledge they should possess to achieve those goals. There are five steps in conducting such a Task analysis:

1. Write a learning goal.

2. Determine the types of learning of the goal.

3. Conduct an information-processing analysis of that goal.

4. Conduct a prerequisite analysis and determine the type of learning of the prerequisites.

5. Write learning objectives for the learning goal and each of the prerequisites.

\section{Importance of Teaching Business Communication}

Writing well and effectively in today's rapidly changing business environment is an essential skill requirement. To accomplish all of our writing goals, we will be using real life scenarios to present writing scenarios and situations students will likely encounter in business and industry. Although some the students have previous workplace 
experience and feel confident in their writing skills, others may be reluctant or insecure because their education, training, and experience have been technologically oriented. This course is to help them express their technological expertise clearly and precisely for any audience. Eliminating jargon and wordiness may be of particular concern. Businesses today isn't just about making money; people judge us based on our thought processes, how we put words on paper, how we logically develop our ideas, and how we back up those ideas.

\section{Learning Objectives and Outcomes}

Learning goals define the way instruction will be delivered. Goals are said to be the intention of the instruction, whereas the objectives are defined as the intended outcome of each instructional activity (Brown and Green,2016). The ABCD approach (Heinich, Molenda, Russell, \& Smaldino,2002) is a great example of creating great objectives. This acronym stands for

Audience: to identify and describe the learners

Behavior: Describes the expectations from the learners after the completion of the instruction

Conditions: The setting for the delivery of the instruction

Degree: The standard of performance.

Determining the intended outcomes beforehand is an important part of instructional design process.

Before attending the business communication course, the students have taken other composition and writing classes where they have worked on writing strong sentences, coherent paragraphs, and essays in various modes. This business communication course will take the students beyond academic writing to study and practice writing, and the kind of documents they will be creating in their professional career. Some of the documents used on daily bases include e-mail, instant messages and text-related messages, memos, business letters, and reports.

\section{Lesson Objectives}

Objective 1: Given the characteristics of effective writing, students will evaluate business writings to determine whether they meet professional standards and ethical guidelines.

Objective 2: Given the need to research and analyze a problem/issue/opportunity within a company, students will apply a process-oriented approach to communicate information in a written message.

Objective 3: Given the need to conform to acceptable formats and implement effective document design, students will compose business communications for different purposes and audiences.

\section{Why Selected Lesson Objectives are Appropriate for Chosen Lesson}

In business world, these days a lot is communicated through writing, both in traditional and electronic platforms. To make requests, to solicit clients, to help existing customers, to inform readers, to motivate staff, to persuade superiors, and to help others make important business decisions. Being able to communicate effectively and write well in business is a critical skill. Writing well can help students perform more effectively and help meet professional goals.

The Course Objectives describe in detail what this course sets out to cover, but the primary objective of this course is to help students learn to write more quickly, easily, efficiently, and effectively in a business environment. Students will accomplish this goal by developing and practicing a three-step writing process, by studying and practicing some basic types of message organizations that are useful in business writing, and by practicing with various types of business documents in various media and communication situations.

\section{Outcome for objective1}

Upon completion of the unit, students will be able to

- Apply audience analysis techniques to successfully deliver a message.

- Evaluate appropriate channels and methods of communication to convey a message for a particular purpose to a specific audience.

- Develop relevant ideas in a clear, concise, and correct manner.

- Apply revision strategies to clarify, correct, and finalize a draft.

- Analyze the writing style of a document (i.e., blog, web announcement, letter, email, infographic, report, etc.) using an audience-centered approach.

- Analyze the routine/good news and/or negative (bad) news message, and explain how the message is typically conveyed. 


\section{Outcome for objective 2}

Upon completion, students will be able to

- Develop a formal or informal audience analysis profile for a variety of writing situations common in business.

- Draft a business message conveying relevant ideas in a clear, concise, and correct manner.

- Create a routine business message using relevant content and the appropriate media.

- Apply guidelines for making ethical and legal communication choices in the creation of a variety of business documents for a variety of situations.

\section{Outcome for objective 3}

Upon completion, students will be able to

- Draft an effective business message in response to a typical business situation.

- Apply principles of interpersonal communication and conflict resolution, along with well-developed writing skills, to create an effective document.

- Analyze the various impressions that the appearance of a document can make.

- Apply good document design features to create an effective document for an external audience.

\section{Creating Events of Instruction and Evaluating Learning}

Assessment is a required component of instructional design. There should be an evaluation developed for each activity aligned in the curriculum. Evaluation is important as it helps the designers and instructors get an idea of the things that are going well and things that need to be improved upon. Evaluation is designed in the very planning stage and continues throughout the course. (Bunson,2012). Assessment is a judgement of student's understanding and performance. After evaluating the students, they are given a feedback to make improvements or are awarded the certificate of completion. Assessments give one an idea about how the students are learning and receiving the information provided. When a formative assessment is conducted, it helps students improve their skills, get feedback, work towards showing their ability and in turn enrich the learning. What students understand as imperative is often influenced by assessment (Russell \& Barefoot 2011).

\section{Formative assessment}

Formative assessment is conducted to get an idea about the effectiveness of teaching and learning. Formative assessment is conducted during the learning and it is done to provide the feedback to the learners. Formative assessments are aligned in a way so that it can monitor learners and assess the comprehension with a view to improve on the teaching, and with a timely feedback learners level of understanding can be assessed (Baleni,2015). It will help the teachers understand if the objectives and goals are being accomplished as aligned in the curriculum. Formative assessment is defined "as the iterative processes of establishing what, how much and how well students are learning in relation to the learning goals and expected outcomes" (Gikandi, Marrow\& Davis, 2011, p.229).

\section{Summative Assessment}

On the other hand, summative assessment includes many different activities to assess the students, including a written test, which could contain multiple choice, true false open-ended questions etc. Summative and formative assessments play an important part in evaluating the effectiveness of a course. Educators and policy makers are of the view that feedback is an essential factor in student learning, and therefore should be prioritized in the curriculum practice (Glazer, 2014).

\section{Feedback}

All the instructors have their own style of conducting instruction in the classroom. The learner assessment is one of the features of classroom instruction. The assessments help the instructors have a knowledge about if something needs to be improved upon. These assessments can be used by the course instructor to assign the level of content knowledge that individual students exhibit as well as providing information about the class as a whole. Such class wide assessment data can be used to inform future changes in instructional design, such as changing teaching methodologies or altering the order or depth of content (Murphy \& Holmes, 2014). 


\section{Gagne's Nine Events of Instruction Table}

\begin{tabular}{|c|c|c|c|c|}
\hline $\begin{array}{l}\text { Event of } \\
\text { Instruction }\end{array}$ & $\begin{array}{l}\text { Objective of this } \\
\text { activity }\end{array}$ & $\begin{array}{l}\text { Teacher's } \\
\text { Performance }\end{array}$ & $\begin{array}{l}\text { Student } \\
\text { Performance }\end{array}$ & $\begin{array}{l}\text { When this event } \\
\text { can be skipped }\end{array}$ \\
\hline $\begin{array}{l}\text { 1. Gain Student's } \\
\text { Attention }\end{array}$ & $\begin{array}{l}\text { Give students an } \\
\text { index card and ask } \\
\text { them to write at least } \\
\text { one expectation } \\
\text { from the course, and } \\
\text { they will write at } \\
\text { least one question } \\
\text { for the instructor } \\
\text { (about the course, } \\
\text { the instructor, life in } \\
\text { general) }\end{array}$ & $\begin{array}{l}\text { Designed with the } \\
\text { Multi Media }\end{array}$ & $\begin{array}{l}\text { Student's } \\
\text { instructions as listed } \\
\text { on flow chart. }\end{array}$ & $\begin{array}{l}\text { It cannot be skipped } \\
\text { as it necessary to } \\
\text { make learners aware } \\
\text { of things they will } \\
\text { learn }\end{array}$ \\
\hline $\begin{array}{l}\text { 2. Inform students } \\
\text { about the learning } \\
\text { objectives. } \\
\text { and } \\
\text { Describe the goals }\end{array}$ & $\begin{array}{l}\text { Send a welcome } \\
\text { message to the } \\
\text { students. E-mail or } \\
\text { post reminders to } \\
\text { students on } \\
\text { discussion } \\
\text { requirements, late } \\
\text { policy, and class } \\
\text { resources and } \\
\text { learning objectives } \\
\text { and goals. }\end{array}$ & $\begin{array}{l}\text { Posted in the } \\
\text { announcement area }\end{array}$ & $\begin{array}{l}\text { Learning objectives } \\
\text { are posted with } \\
\text { lesson Power Point } \\
\text { slide. }\end{array}$ & Not skipped. \\
\hline $\begin{array}{l}\text { 3. Stimulate recall } \\
\text { of prior learning }\end{array}$ & $\begin{array}{l}\text { Students will } \\
\text { consider successful } \\
\text { messages they have } \\
\text { received, either as a } \\
\text { professional or as a } \\
\text { customer. How did } \\
\text { the errors in } \\
\text { spelling, grammar, } \\
\text { punctuation, and } \\
\text { content affect the } \\
\text { success of those } \\
\text { messages, and } \\
\text { student's reaction or } \\
\text { response to the } \\
\text { message }\end{array}$ & $\begin{array}{l}\text { Developed within } \\
\text { Multi Media }\end{array}$ & $\begin{array}{l}\text { A discussion is } \\
\text { posted under } \\
\text { discussion area. } \\
\text { And is required for } \\
\text { all the students }\end{array}$ & $\begin{array}{l}\text { This is a } \\
\text { requirement. }\end{array}$ \\
\hline $\begin{array}{l}\text { 4. Present and Cue } \\
\text { the material to be } \\
\text { learnt. }\end{array}$ & $\begin{array}{l}\text { Students are } \\
\text { provided with an } \\
\text { over view of the } \\
\text { syllabus and what } \\
\text { would be covered in } \\
\text { the class. }\end{array}$ & $\begin{array}{l}\text { Developed within } \\
\text { the Power Point. }\end{array}$ & $\begin{array}{l}\text { Students follow } \\
\text { along with the } \\
\text { instructions and } \\
\text { guidance provided } \\
\text { within the Doc } \\
\text { sharing. }\end{array}$ & $\begin{array}{l}\text { This is again very } \\
\text { important and will } \\
\text { not be skipped. }\end{array}$ \\
\hline $\begin{array}{l}\text { 5. Provide guidance } \\
\text { for learning to } \\
\text { students }\end{array}$ & $\begin{array}{l}\text { Students are made } \\
\text { aware of available } \\
\text { sources. Class } \\
\text { resources in the } \\
\text { following locations: } \\
\text { Student Resources } \\
\text { (library and } \\
\text { tutorials) } \\
\text { Doc Sharing extra } \\
\text { help handouts and } \\
\text { rubrics }\end{array}$ & $\begin{array}{l}\text { Developed within } \\
\text { the Power Point. } \\
\text { Videos and online } \\
\text { tutorials. }\end{array}$ & $\begin{array}{l}\text { Students use tutorial } \\
\text { links as directed in } \\
\text { doc sharing and } \\
\text { complete } \\
\text { assignments, }\end{array}$ & $\begin{array}{l}\text { Students are asked to } \\
\text { view the tutorials for } \\
\text { extra help }\end{array}$ \\
\hline
\end{tabular}




\begin{tabular}{|l|l|l|l|l|} 
& $\begin{array}{l}\text { Peak Performance } \\
\text { tab } \\
\text { Blank Slate Videos }\end{array}$ & & & \\
\hline $\begin{array}{l}\text { 6. Activate learner } \\
\text { performance }\end{array}$ & $\begin{array}{l}\text { Active in class } \\
\text { activities based on } \\
\text { the things learned in } \\
\text { groups and } \\
\text { individually helps } \\
\text { keep track of the } \\
\text { performance. }\end{array}$ & $\begin{array}{l}\text { Developed with the } \\
\text { Power Point tutorial. }\end{array}$ & $\begin{array}{l}\text { Students will follow } \\
\text { guided instructions } \\
\text { by progressing } \\
\text { through the Power } \\
\text { Point and video } \\
\text { tutorial. }\end{array}$ & Not skipped. \\
\hline $\begin{array}{l}\text { 7. Provide } \\
\text { Feedback to the } \\
\text { learners }\end{array}$ & $\begin{array}{l}\text { Immediate feedback } \\
\text { is provided in class } \\
\text { as well as through } \\
\text { discussions and } \\
\text { assignments. }\end{array}$ & . & $\begin{array}{l}\text { Based on quizzes, } \\
\text { group discussions } \\
\text { and assignment }\end{array}$ & $\begin{array}{l}\text { Formative feedback } \\
\text { to the learner, } \\
\text { summative } \\
\text { assessment due at } \\
\text { end of course }\end{array}$ \\
\hline $\begin{array}{l}\text { 8 Assess } \\
\text { performance of the } \\
\text { students. }\end{array}$ & $\begin{array}{l}\text { Weekly quiz on the } \\
\text { things learned and } \\
\text { the assignment } \\
\text { based, and the } \\
\text { concepts covered. }\end{array}$ & $\begin{array}{l}\text { Learners are } \\
\text { provided feedback }\end{array}$ & $\begin{array}{l}\text { Assessment helps } \\
\text { both students as well } \\
\text { as faculty }\end{array}$ & $\begin{array}{l}\text { Not skipped. } \\
\text { 9 Enhance } \\
\text { retention and } \\
\text { transfer }\end{array}$ \\
$\begin{array}{l}\text { Work towards } \\
\text { writing in real life } \\
\text { scenarios-based } \\
\text { assignment. }\end{array}$ & $\begin{array}{l}\text { Applying learning in } \\
\text { real-life situations is } \\
\text { a step towards } \\
\text { Mastery Learning. }\end{array}$ & $\begin{array}{l}\text { Students have } \\
\text { tutorial available on } \\
\text { eCollege for } \\
\text { refresher and review } \\
\text { as needed. }\end{array}$ & $\begin{array}{l}\text { Class is mandatory } \\
\text { for students as part } \\
\text { of their credits }\end{array}$ \\
\hline
\end{tabular}

Adapted from K. Kruse, Gagne's Nine Events of Instruction: An Introduction. (2008), Retrieved from http://www.utsweb.net/Instructional\%20Design\%20Resources/GagneStyle.pdf

\section{Learner evaluation}

Assessment of educational outcomes plays an increasingly important role.Formative evaluation is the "collection of data and information during the development of instruction that can be used to improve the effectiveness of the instruction" (Dick, Carey, \& Carey, 2011). The purpose of formative evaluation is to identify specific errors and problems that can be corrected. They suggest focusing on the effectiveness of the instructional strategies by focusing on questions addressed to experts, instructors, and students (Dick, Carey, \& Carey, 2011):

- Is the material appropriate for the desired outcomes?

- Are the objectives and outcomes aligned?

- Are students able to understand the material?

- Do learners find the materials relevant to their needs, interests, and are comfortable and satisfied with what they have learnt.

\section{Formative Evaluation}

For formative evaluation of learners, they are given multiple choice and true false quiz at the end of the lecture. The learners are evaluated to see their understanding, and then provided with appropriate feedback. Here is a sample formative assessment quiz:

- The quiz is comprised of 5 multiple choice questions (2 points each) and 10 short answer questions (5 points each), covering the contents of the Writing Elements Training Module.

- Your responses to numbers 6-15 should correct a specific writing element error. The following lists the element to correct for each quiz item in questions 6-15:

6. Completeness,

7. Clarity,

8. Conciseness,

9. Active Voice,

10. Tone,

11. You-Attitude, 
12. Nondiscriminatory Language,

13. Confidence,

14 Fluency,

15. Graphic Highlighting.

Evaluation:

- Evaluate if student has effectively addressed not only the focus area (e.g., active voice), but has also correctly written the sentence to include other areas of English conventions such as grammar, spelling, punctuation, clarity, conciseness, fluency, etc.

- Evaluate and provide feedback if the student has somewhat effectively addressed the focus area, but also has some errors that affect the readability of the sentence.

- Student needs the feedback and additional understanding of the concepts if the student has attempted to address the focus area, but has several other errors that affect the readability of the sentence.

\section{Summative Evaluation}

For summative evaluation, the students will have to take a final exam where there would be real life scenario questions and students will be assessed based on the following:

- A clear, well-organized description of the problem and explanation of solution

- Inclusion of specific supporting details and evidence

- Demonstration of a clear purpose and awareness of the audience

- Effective development and sequencing of ideas

- Appropriate style and tone for a business document

- Standard written English grammar, spelling, and punctuation

While formative evaluation is used to improve the effectiveness of instruction, the purpose of summative evaluation is to verify the effectiveness of instruction with the target audience and decide whether the materials should be used in the future.

\section{Conclusion}

Effective communication is important for every company's success, today more than ever. As our workplace becomes more and more global in focus, the need to be understood efficiently and correctly has become an imperative. Whether that communication is internal between employees of a company, or external between employees and customers, clients, or contractors, success in business depends upon mastering good communication skills. In this course, we will focus on improving student's written communication, as well as understanding the tools that can help them become an effective communicator. Instruction is designed with a specific purpose of making improvements and introducing better variables.

Before the instructional design process can be started many questions like who requested the change and the variables surroundings that change and in what environment it should occur, should be answered. The information gathered during this assessment helps designers to have a clear idea about what needs to be developed. Professional writing is a specialized field of communication whose purpose is to convey information accurately and effectively. One in a professional environment can have the greatest ideas in the world, but those ideas will be of no importance to one's company, one's readers, or one's career if those ideas are not expressed clearly and with a positive tone, that meets the readers' needs. In an age when we have so many media choices and so many written messages to create, having a strong and well-practiced process is important to one's success. In addition, knowing when to use the right formats for writing messages is important. It makes all the difference between how one's message is being read and understood. 


\section{References}

Brown, A., \& Green, T. (2016). The essentials of instructional design: Connecting fundamental principles with process and practice (Third ed.). New York, NY: Routledge.

Baleni, Z. G. (2015). Online formative assessment in higher education: Its pros and cons. Electronic Journal of ELearning, 13(4), 228-236.

Carnes, L., Awang, F., \& Smith, H. (2015). Assurance of learning in a writing-intensive business course. Journal of Case Studies in Accreditation and Assessment, 4.

Conrad, D., \& Newberry, R. (2012). Identification and instruction of important business communication skills for graduate business education. Journal of Education for Business, 87(2), 112-120. doi:10.1080/08832323.2011.576280.

Davies, C., \& Birbili, M. (2000). What do people need to know about writing in order to write in their jobs? British Journal of Education Studies, 48 (4), 429-445.

Dick,W., Carey, L., \& Carey, J. (2011). The systematic design of instruction. (7th Edition). Pearson.

Docherty, P., Tse, H., Forman, R., \& McKenzie, J. (2010). Extending the principles of intensive

writing to large macroeconomic classes. Journal of Economic Education, 41(4), 370-382.

Glazer, N. (2014). Formative plus summative assessment in large undergraduate courses: Why both? International Journal of Teaching and Learning in Higher Education, 26(2), 276-286.

Gikandi, J.W., Morrow, D, \& Davis N.E. (2011). Online formative assessment in higher education: A review of literature. Computers \& Education 57: 2333-2351.

Grinols, A., \& Waller, R. (2010). Team teaching: Old chefs come up with new recipe. Business Communication Quarterly, 73, 101-105.

Heinich,R.,Molenda,M，Russell,J.,\& Smaldino,S.(2002).Instructional media and technology for learning $\left(7^{\text {th }}\right.$ ed).Upper SaddleRiver.NJ:Merrill/Prentice Hall.

Hynes, G., \& Sigmar, L. (2009). The importance of business communication courses in employer hiring decisions. Huntsville, TX: Sam Houston State University.

Kellolg,R.T.,Whiteford,A.P.(2009).Training advanced writing skills: The case for deliberate practice. Educational Psychologist 44(4):250-266. DOI: 10.1080/0046152090321360

Lenhart, A., Arafeh, S., Smith, A., \& Macgill, A. R. (2008). Writing, technology, and

teens. The National Commission on Writing, 1-83.

Mascle, D. D. (2013). Writing Self-Efficacy and Written Communication Skills. Business Communication Quarterly, 76(2), 216-225. doi:10.1177/1080569913480234.

May, G. L., Thompson, M. A., \&Hebblethwaite, J. (2012). A Process for assessing and improving business writing at the MBA level. Business Communication Quarterly, 75(3), 252-270. doi:10.1177/1080569912441822.

Middleton, D. (2011). Students struggle for words. The Wall Street Journal.

National Commission on Writing. (2004). Writing: A ticket to work... or a ticket out. New York, NY: College Entrance Examination Board.

Parent, J. D., Nielsen-Dube, K., Stowe, K. F., Schwartz, L. A., Sendall, P., \& Cain, K. S. (2011). Successful writing skill acquisition within the business curriculum. Journal of The Academy Of Business Education, 1256-73.

Quible, Z. (2006). Impact of error labeling on error elimination in business writing. Business Communication Quarterly, 68, 8-24.

Russell, M., \& H. Barefoot. (2011). Explorations of technology enhanced assessment; Bringing learning from theory and practice. Higher Education Academy Evidence Net Briefing Paper.

Smith,P.L.,\&Regan,T.J.(1999).Instructional design( $2^{\text {nd }}$ ed.).Hoboken,NJ:Wiley.

The National Commission on writing for America's families, schools, and colleges (2004).

Writing: A ticket to work or a ticket out. 1-44.

Waldeck, J., Durante, C., Helmuth, B., \& Marcia, B. (2012). Communication in a Changing World: Contemporary Perspectives on Business Communication Competence. Journal of Education For Business, 87(4), 230-240. doi:10.1080/08832323.2011.608388. 